e ISSN-0976-7223 | Visit Us - www.researchjournal.co.in

DOI : 10.15740/HAS/IJAE/7.2/334-339

\title{
Water balance study in an agricultural watershed for evaluating ground water potential at Sindewahi
}

\section{ASHOK R. MHASKE, V.P. UBARHANDE AND S.M. TALEY}

See end of the Paper for authors' affiliation

Correspondence to :

ASHOK R. MHASKE

Department of Soil Water Conservation Engineering, College of Technology and Engineering, Dr. Panjabrao Deshmukh Vidyapeeth, AKOLA (M.S.) INDIA Email : mhaskear@gmail.com
-ABSTRACT : Water balance study on Zonal Agricultural Research Station, Sindewahi, Distt.Chandrpur was conducted on 9 open wells during the rainfall 2005-06. During the year total rainfall received was only $1422 \mathrm{~mm}$. The study indicated that the availability of total water balance during the year was about 964.94 $\mathrm{mm}(67.84 \%)$ of the total rainfall. Out of the total rainfall 8per cent was surface runoff, about 18.67 per cent ground water recharge ( $\mathrm{Yg}$ ) and 37 per cent soil moisture storage. Maximum (75.45 ha-m) ground water storage was observed in the month of September followed by 63.45 ha-m in the month August and minimum (16.50 ha-m) in the month of June. The monthly ground water fluctuations were determined by considering the month of May as the driest season. The average ground water level was found higher $455 \mathrm{~cm}$ in the month of September and maximum seasonal fluctuation of ground water level was observed in well No. 2 i.e. 612 $\mathrm{cm}$. The study indicated the annual status of ground water potential.

- KEY WORDS : Precipitation, Water balance, Ground water potential, Specific gravity yield, Seasonal fluctuation

— HOW TO CITE THIS PAPER : Mhaske, Ashok R., Ubarhande, V.P. and Taley, S.M. (2014). Water balance study in an agricultural watershed for evaluating ground water potential at Sindewahi. Internat. J. Agric. Engg., 7(2): 334-339. 